\title{
Using energy budget data to assess the most damaging life-stage of an agricultural pest Mocis latipes (Guenèe, 1982) (Lepidoptera - Noctuidae)
}

\author{
Assunção-Albuquerque, MJT. ${ }^{\mathrm{a} *}$, Peso-Aguiar, MC. ${ }^{\mathrm{b}}$ and Albuquerque, FS. ${ }^{\mathrm{a}}$ \\ ${ }^{a}$ Edificio de Ciências, Universidad Alcalá de Henares - UAH, \\ Ctra. Madrid, Barcelona, Km 33.6, 28871, Alcalá de Henares, Madrid, Spain

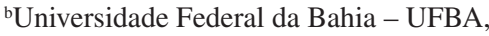 \\ Rua Barão de Geremoabo, 147, Campus de Ondina, CEP 40170-290, Salvador, BA, Brazil \\ *e-mail: mariajose.teixeira@alu.uah.es
}

Received January 12, 2009 - Accepted June 1, 2009 - Distributed August 31, 2010

(With 2 figures)

\begin{abstract}
There is much evidence to support that Mocis latipes larvae (Guenèe, 1852) are the most dangerous pasture pest and usually cause large environmental losses. However, no studies have been carried out to identify the instars during which this moth causes the most damage to the environment. Here we calculate $M$. latipes larval energy budget to assess its consumption across all instars and estimate the consumption/amount of plant biomass required to complete its larval development. Assimilation, respiration, consumption, excretion, gross growth efficiency and net growth efficiency were calculated. Pearson correlations were used to identify the best predictors that influenced larval growth and weight. Across all instars consumption increased exponentially, especially during the last phase. M. latipes larvae consumed ca $13.8 \%$ of total food from the first to the fifth instar, whereas during the sixth instars these larvae consumed ca $72.6 \%$. Results also show that the best gross growth and net growth efficiency were obtained when larvae reached the fifth instar. The results also show that one larva of Mocis latipes consumes $1.02 \mathrm{~g}$ (dry weight) of Paspalum maritimum (Trin) in 19 days. Overall, our results indentified the sixth instar as the most destructive instar of this insect. Thus, once we know the most destructive instars of this pest, measures can be taken to disable M. latipes larval development and consequently stop their increase in plant consumption, reducing ecological and economic damage. This knowledge may eventually lead to reduced agricultural damage and contribute to sustainable farming strategies.
\end{abstract}

Keywords: moths, energy balance, pasture plagues, Noctuidae.

\section{Utilizando o balanço energético de Mocis latipes (Guenèe, 1982) (Lepidoptera - Noctuidae) para identificar o estágio do ciclo de vida mais perigoso de uma praga de pastos}

\begin{abstract}
Resumo
Inúmeras evidências indicam a larva de Mocis latipes (Guenèe, 1852) como uma das pragas de pastagem mais perigosas e que comumente causam grandes perdas ambientais. Entretanto, nenhum estudo foi feito para identificar qual a fase de desenvolvimento em que o dano ao ambiente é maior. Neste trabalho, nós calculamos o balanço energético larval de M. latipes para descobrir o consumo em cada instar e estimar o consumo requerido para completar o desenvolvimento larval. A assimilação, respiração, excreção, consumo e os coeficientes, bruto e líquido, do crescimento foram calculados. Correlações de Pearson foram usadas para identificar os preditores que mais influenciavam o crescimento da larva. Resultados indicaram que o consumo aumentou exponencialmente durante os instares, especialmente durante o último instar. Larvas de M. latipes consumiram aproximadamente 13,8\% do recurso alimentar total entre o primeiro e o quinto instar, enquanto que no sexto instar consumiram $72,6 \%$. Os resultados também indicaram que o consumo bruto e o consumo líquido foram maiores nos últimos instares. Também se verificou que apenas uma larva consumiu 1,02 g de Paspalum maritimum (Poaceae) em 19 dias. Em resumo, nossos resultados identificaram o sexto instar como o mais destrutivo. Uma vez que se conheça o instar mais destrutivo, medidas mais eficazes podem ser tomadas para inibir o desenvolvimento larval de $M$. Latipes e o crescimento significativo do seu consumo e, consequentemente, reduzir danos ao ambiente. Este conhecimento pode, eventualmente, contribuir para reduzir danos à agricultura e contribuir para seu desenvolvimento sustentável.
\end{abstract}

Palavras-chave: Mocis, mariposa, praga de pastos, balanço energético. 


\section{Introduction}

Many studies support that a great number of species of Lepidoptera are the most dangerous pasture pests, and usually cause large environmental losses (Panizzi and Parra, 1991; Oliveira, 1997; Ferreira et al., 2002). The grass looper, Mocis latipes (Guenèe, 1852) (Lepidoptera: Noctuidae) is a polyphagous insect that feeds mainly on herbaceous plants, crops or wild species, with a special preference for pasture species such as grasses, oats, wheat, corn, and rice (Silva et al., 1968; Lourenção et al., 1982; Cruz and Santos, 1983; Santos et al., 1994; Silva et al., 1994; Oliveira, 1997). Also, this insect can have a large impact on cultivated species such as cotton, coffee, soybeans, peanuts, and also tree and shrub species (Silva et al., 1968; Lübeck et al., 1995; Zanuncio et al., 1995; Gomez, 1998; Gallo et al., 2002). The grass looper it is widely distributed throughout the American continent, from north of Canada to Argentina (Reinert, 1975; Cruz and Santos, 1983; Silva et al., 1991; Lima et al., 1998). In Brazil, this species is present in almost all states, mainly in Bahia, where agricultural and livestock activities are well developed (Salles et al., 1979; Costa et al., 1983; Santos et al., 1994; Silva et al., 1994; Lübeck et al., 1995; Ferreira et al., 1998; Ferreira et al., 2002).

M. latipes's life cycle is characterised by 6 to 7 instars and 50 days are necessary for total larval development (Santos et al., 1994; Gallo et al., 2002). During the last instar, the larva becomes a pupa using plant leaves to produce a protective cocoon, where it completes its metamorphosis and subsequently transforms into a $42 \mathrm{~mm}$ long moth (Lourenção et al., 1982; Costa et al., 1983; Silva et al., 1991; Oliveira, 1997; Valério, 1997; Ferreira et al., 2002). Post larval stages are appropriate for measuring energy budgets and to evaluate how the digestibility of plant material in their diet influences growth rates (Jiménez-Yan et al., 2006). The energy budget of an individual allows the quantification of energy flow throughout the lifetime of an organism, describing the rates at which the organism assimilates and uses energy for maintenance, growth and reproduction (Koojima, 2000, 2001; Wuenschel et al., 2004; Lemos et al., 2006).

Our main purpose in this paper was to calculate $M$. latipes larval energy budget and then estimate the amount of consumed food required to complete its larval development. Specifically, we hypothesised that the last instars play a major role in determining the growth of $M$. latipes. Although there is extensive knowledge about $M$. latipes life history, as far as we know this is the first study that describes its energy budget.

\section{Material and Methods}

\subsection{Experimental data}

This study was developed at the Laboratory of Entomology at the Bahia Agricultural Development Company (EDBA), from the Government Agricultural Secretary, in Salvador (Bahia State), Brazil, from January to June 2003. Three hundred specimens of M. latipes were randomly captured from a natural population in Salvador $\left(38^{\circ} 2^{\prime} \mathrm{S}\right.$ and $\left.13^{\circ} 13^{\prime} \mathrm{W}\right)$, and were used to calculate the $M$. latipes larval energy budget and to estimate larval growth throughout the instars. These insects were maintained in the laboratory at a constant temperature of $24{ }^{\circ} \mathrm{C}$ and relative humidity of $70 \%$.

\subsection{Diet preparation and feeding procedures}

Individuals were separated into three pairs of moths by sex and age. These pairs were put into cylindrical plastic containers of $18 \mathrm{~cm}$ diameter and $20 \mathrm{~cm}$ high, internally lined with filter paper, used to facilitate the hatching of moth eggs. Inside these recipients, a $1 \%$ honey solution was put into a glass bottle in order to sustain the adult moths. Feeding took place by capillarity, dipping a bit of cotton into the honey solution, which was changed daily to avoid fermentation. Petri dishes (16 $\mathrm{cm}$ in diameter) were used to stabilise the containers.

Insects were placed into a refrigerator at $7{ }^{\circ} \mathrm{C}$ for 20 minutes, leaving individuals partially anesthetised. Then, moths were removed from the containers and eggs were separated and placed into Petri dishes until they hatched. One hundred larvae per couple were collected and fed with $400 \mathrm{~cm}^{2}$ of Paspalum maritimum (Trin). This grass is frequently used as a pasture species, and has a high nutritional value (Lorenzi, 1982).

\subsection{Energy budget}

Mocis latipes basic energy budget parameters were obtained following Petrwsewicz and Macfadyen (1970). Accordingly, we included a set of seven variables:

- Consumption (C) was determined by ingestion rate. At each larval instar, initial dry weight of $P$. maritimum was obtained. Grass was placed into a kiln at $60{ }^{\circ} \mathrm{C}$ for 24 hours. The same procedure was used to obtain the weight of $P$. maritimum unconsumed biomass. Consumption was defined as the difference between initial dry weight of grass and the dry weight of the rejected food;

- Excretion $(\mathrm{F})$ was considered as a portion of energy or food consumption not absorbed and excreted as faeces. Initially, faeces and unconsumed food were separated by a gravimetric method. Thus, faeces were collected; quantified and weighed. Samples were put into a kiln at $60{ }^{\circ} \mathrm{C}$ for 24 hours and then dry weight was obtained;

- Instantaneous production $(\mathrm{P})$ of each instar was obtained following the equation $\mathrm{P}=\mathrm{Pi}_{\mathrm{P}}+\mathrm{Pex}_{\mathrm{i}}-\mathrm{P}_{\mathrm{i}}$, where $\mathrm{P}_{\text {ip }}$ was the initial larval dry weight at the posterior instar, Pex $_{\mathrm{i}}$ was the exuviae larval weight of the instar $\mathrm{i}$ and $\mathrm{P}_{\mathrm{i}}$ was the initial larval weight at the instar i;

- Assimilation (A) and Respiration (R) parameters were obtained indirectly, using consumption, excretion and instantaneous production, using the equations: $\mathrm{A}=\mathrm{C}-\mathrm{F}$ and $\mathrm{R}=\mathrm{A}-\mathrm{P}$; 
- Assimilation efficiency (U) was considered as part of consumed food retained for physiological purposes (Martinez et al. 1995) and was calculated as the rate of assimilation and consumption $(\mathrm{U}=\mathrm{A} / \mathrm{C})$;

- Gross growth efficiency $\left(\mathrm{K}_{1}\right)$ was considered as a portion of the consumption converted into organic biomass $\left(\mathrm{K}_{1}=\mathrm{P} / \mathrm{C}\right)$; and

- Net growth efficiency $\left(\mathrm{K}_{2}\right)$ represented the assimilated energy converted to growth and was obtained by the formula $\left(\mathrm{K}_{2}=\mathrm{P} / \mathrm{A}\right)$. These values are represented as a percentage.

The energy budget was finally calculated, quantifying the total food consumed, excreted, and assimilated at each larval instar. Average egg weight was recorded and used as the initial weight of the life cycle. Larvae were placed into plastic containers, and their survival estimated, counting the number of live and dead individuals.

\subsection{Statistical analyses}

After checking for normal distribution and homogeneous variance, Pearson's correlations were used to relate which factors are most associated with larval development throughout the instars, using the software pack Statistica (StatSoft, Inc., 2003).

\section{Results}

$M$. latipes ontogenetic energetic budget parameters presented great oscillations between instars. Larval weight increased in all instars. M. latipes consumption exhibited an exponential increase, especially during the last instars. Consumption values ranged between $0.43-7.02 \mathrm{mg} / \mathrm{ind} / \mathrm{h}$ from the first to the fifth instar, representing $13.8 \%$ of total consumed food. At the last instar this moth consumed $37 \mathrm{mg} / \mathrm{ind} / \mathrm{h}(72.6 \%)$ of total food. Not surprisingly, larval excretion followed a similar pattern. From the total food consumed, $24.3 \mathrm{mg} / \mathrm{ind} / \mathrm{h}$ (48\%) were excreted. Most of these excreta, $21.8 \mathrm{~g}(89.4 \%)$, were discharged at the sixth instar. In relation to assimilated energy, the assimilation efficiency, calculated as the proportion of absorbed energy, was $44 \%$. This assimilation showed a slight increment until the fifth instar. A similar pattern was found for respiration and growth rates (Figure 1). Further, the results also showed that one larva of $M$. latipes consumed $1.02 \mathrm{~g}$ (dry weight) of Paspalum maritimum (Trin) during its larval cycle, in 19 days. Taking this into account, we verified that 90.8 larvae needed $1 \mathrm{~m}^{2}$ of $P$. maritimum of $20 \mathrm{~cm}$ leaf length and $92.65 \mathrm{~g}$ (dry weight) in order to complete their life cycle.

The gross growth efficiency $\left(\mathrm{K}_{1}\right)$ and energy consumption channelled into growth $\left(\mathrm{K}_{2}\right)$ showed similar results. The best gross $(35 \%)$ and net growth (43\%) efficiency was obtained when larvae reached the fifth instar. However, a higher increase was noted for $\mathrm{K}_{2}$ between the first and the second instars. The assimilation efficiency (U) was $20 \%$ at the three initial instars, with a progressive linear decrease until the last instar (Figure 2).

The relationship between larval growth and weight with bioenergetic variables showed different patterns (Table 1). Simple correlations indicated that the assimilation coefficient was the most strongly correlated parameter with larval weight, while consumption and excretion were the most significant coefficients correlated with moth growth.

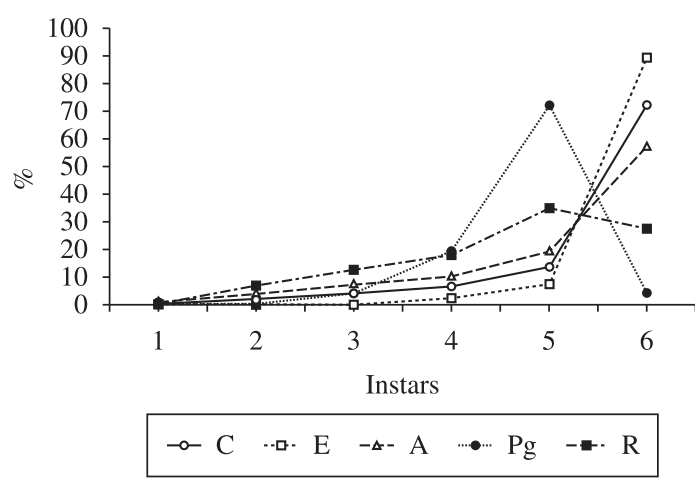

Figure 1. Consumption (C), Faeces, Excretion (E), Assimilation (A), Growth (Pg) and Respiration (R) of Mocis latipes across the different stages of larval development.

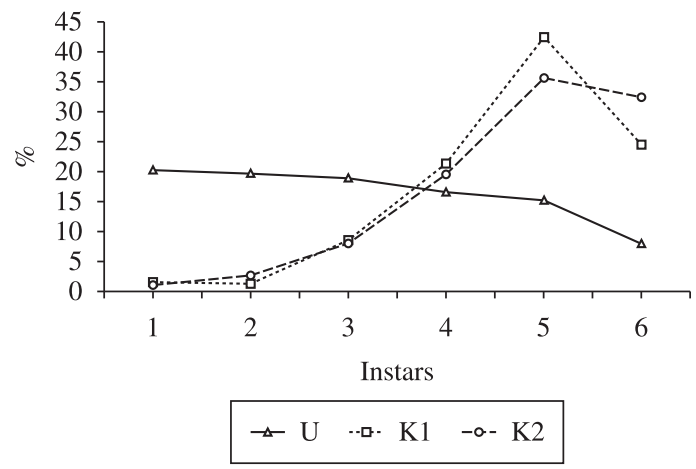

Figure 2. Estimated values of assimilated energy (U), gross growth efficiency (K1) and energy consumed channelled into growth (K2) throughout Mocis latipes larval development.

Table 1. Pearson correlations of weight and growth of Mocis latipes with its Consumption, Excretion, Assimilation and Respiration (R). (*P < 0.05).

\begin{tabular}{lllllll}
\hline & \multicolumn{2}{c}{ Weight $(\mathrm{g})$} & & \multicolumn{2}{c}{ Growth } \\
\cline { 2 - 3 } \cline { 5 - 6 } & \multicolumn{1}{c}{$\mathbf{r}$} & Probability & & r & Probability \\
\hline Consumption & 0.149 & $>0.1$ & & $0.932^{*}$ & $<0.001$ \\
Excretion & 0.070 & $>0.1$ & & $0.936^{*}$ & $<0.0001$ \\
Assimilation & $0.750^{*}$ & $<0.01$ & & $0.446^{*}$ & $<0.01$ \\
Respiration & $0.422^{*}$ & $<0.01$ & & $0.545^{*}$ & $<0.01$ \\
\hline
\end{tabular}




\section{Discussion}

Our data indicated that energy partitioning (\% of ingestion) of $M$. latipes larvae was markedly different from the first to the sixth instar. Consumption by $M$. latipes larvae was substantially greater during the last instar, which agrees with previous findings in different parts of the world, supporting that $M$. latipes larval consumption is significantly correlated with metabolic changes during their life cycle (Parra, 1980; Crócomo and Parra, 1985; Panizzi and Parra, 1991; Busato et al. 2002; Ferreira et al., 2002). Furthermore, our data also indicated that consumption by $M$. latipes larvae was strongly correlated with their growth. This parameter is fundamental in the life cycle of $M$. latipes and this importance becomes evident between the third and sixth instars (Silva and Carvalho, 1986). This greater demand may be related to the increase in metabolic rate, the energy required for digestion, absorption, nutrient storage, synthesis and deposition of tissue components (Lemos et al., 2006). Thus, similar to these previous studies, our results support the hypothesis that the last instars play a major role in determining the growth of $M$. latipes. In the same manner, excreted energy was substantially augmented when consumption increased. Excreta values may be related to digestible food matter and assimilation efficiency, suggesting a high digestibility of the diet.

Studying the energy budget of wood-feeding larvae of Corymbia rubra (Linnaeus, 1758), Walczynska (2007) found that assimilation in these larvae was $29.1 \%$. JimenesYan (2006) found that the assimilation of shrimp larvae (Litopenaeus vannamei (Boone, 1931): Decapoda - Penaeidae) was $41 \%$. Both authors conclude that these values represent a strong/high diet digestibility. The assimilation efficiency M. latipes larvae was similar, suggesting a high absorbability of Paspalum maritimum (Trin.), which is corroborated by the high assimilated energy during the last instars (Figure 1). In the same way, gross (K1) and net (K2) growth efficiencies were high until the fifth instar.

Changes in behaviour (i.e. mobility, time spent in searching for food) would explain the routines in their metabolism (Jimenez-Yan, 2006). Furthermore, the total available food is not completely absorbed, because only a portion of this food is really digested (Petrwsewicz and Macfadyen, 1970). From the total assimilated energy, a fraction is lost through oxidative processes and metabolism maintenance and another portion is used for growth, reproduction, and cell regeneration (Busato et al. 2002). Moreover, the quality of consumed food could influence larval growth and also interrupt the larva's life cycle (Felipe and Zucoloto, 1993; Busato et al., 2002; Ferreira et al., 2002; Heard et al., 2005), and also affects growth rate and weight, and consequently the moth's growth (Scriber and Slansky-Jr., 1981). The ecology and behaviour of insects could be strongly influenced by nutritional factors (Santos et al., 2003). When the nutritional quality of consumed food affects larval growth, this insect can increase consumption and excretion, and consequently increase its damaging/destructive power. Other pasture pests of the Noctuidae family, like Anticarsia gemmatalis (Hübner), also cause great damage to agriculture during their larval phase (Gallo et al., 2002). Larvae of A. gemmatalis (Hübner,
1818) exhibit an elevated consumption throughout their larval development, and usually consume $90 \mathrm{~cm}^{2}$ of grass leaves to complete their ontogenetic development (Gallo, et al., 2002; Andrade et al., 2004). At a rice plantation, Ferreira et al. (2002) found that 5.5 larvae $/ \mathrm{m}^{2}$ were necessary to reduce more than $50 \%$ of this crop. This indicates that consumption may be directly related to the crop species. The higher assimilation efficiency of $M$. latipes larvae seems to be related to an increase in their consumption during the last instars and consequently an increase in their potential damage to agriculture.

Finally, the use of energy budgets can help optimise pest control and derive in the practical development of optimal pest control strategies, once we know at which instars these species cause the most pasture damage (van Oijen et al., 1995; Ratsak, 2001). The ontogenetic balance of M. latipes indicated little consumption during the three initial instars and a substantial increase at the fifth instar. Using this information, effective measures can be taken to disable $M$. latipes larval development and consequently avoid the strong increase in their consumption, reducing ecological and economic damage. This knowledge may eventually lead to reduced agricultural damage and contribute to sustainable farming strategies.

Acknowledgements - The authors wish to thank the staff of the EBDA laboratory for making their equipment labs available for our study. Our most sincere gratitude to Lucía Gálvez, who provided very useful comments on this paper.

\section{References}

ANDRADE, FG., NEGREIRO, MCC. and FALLEIROS, AMF., 2004. Aspectos dos mecanismos de defesa da lagarta da soja Anticarsia gemmatalis (hübner, 1818) relacionados ao controle biológico por Baculovirus anticarsia (agmnpv). Arquivos do Instituto Biológico, vol. 71, no. 3, p. 391-398.

BUSATO, GR., GRÜTZMACHER, AD., GARCIA, MS., GIOLO, FP. and MARTINS, AF., 2002. Consumo e utilização de alimento por Spodoptera frugiperda (J.E. Smith) (Lepidoptera: Noctuidae) originária de diferentes regiões do Rio Grande do Sul, das culturas do milho e do arroz irrigado. Neotropical Entomology, vol. 31, no. 4 , p. 525-529.

COSTA, JM., CORREIA, JS., SANTOS, ZFDAF. and FERRAZ, MCVD., 1983. Pragas das pastagens do estado da Bahia e meios de controle. Bahia: Empresa de Pesquisa Agropecuária da Bahia. 39 p. (Circular Técnica, 6)

CRÓCOMO, WB. and PARRA, JRP., 1985. Consumo e utilização de milho, trigo e sorgo por Spodoptera frugiperda (Smith, 1797) (Lepidoptera: Noctuidae). Revista Brasileira Entomologia, vol. 29, p. 225-260.

CRUZ, I. and SANTOS, JP., 1983. Estudo comparativo da biologia de Mocis latipes em dieta artificial em Folhas de Milho e Sorgo. Pesquisa Agropecuária Brasileira, vol. 18, no. 2, p. 85-90.

FELIPE, MC. and ZUCOLOTO, FS., 1993. Estudo de alguns aspectos da alimentação em Ascia monuste GODART (Lepidoptera, Pieridae). Revista Brasileira de Zoologia, vol. 10, no. 2, p. 333-341.

FERREIRA, E., VIERA, NRA. and RANGEL, PHN., 1998. Perda de rendimento de grãos provocados por pragas em arroz de terras altas, cultivar maravilha. In Anais do 17 Congresso Brasileiro de Entomologia. Rio de Janeiro: SEB. 
FERREIRA, E., DISTEFANO, JG., NETO, FPM., SILVA, DR., ALENCAR, FCN., CARVALHO, JD., MOREIRA, LG. and VILELA FILHO, MJ., 2002. Influência de insetos e plantas daninhas na produção de grãos de arroz-cultivar maravilha. Ciência e Agrotecnologia, p. 1451-1458. (edição especial)

GALLO, D., NAKANO, O., SILVEIRA NETO, S., CARVALHO, RPL., BATISTA, GC., BERTI FILHO, E., PARRA, JRP., ZUCCHI, RA., ALVES, SB., VENDRAMIN, JD., MARCHINI, LC., LOPES, JRS. and OMOTO , C., 2002. Manual de Entomologia Agrícola. Piracicaba: FEALQ. 920 p.

GOMEZ, AS., 1998. Controle de Mocis latipes (GUENÉE, 1852), em Soja recém-emergida sob palhada dessecada, no Mato Grosso do Sul. [S.1.]: EMBRAPA.

HEARD, TA., PAYNTER, Q., CHAN, R. and MIRA, A., 2005. Malacorhinus irregularis for biological control of Mimosa pigra: host-speciWcity, life cycle, and establishment in Australia. Biological Control, vol. 32, no. 2, p. 252-262.

JIMÉNEZ-YAN, L., BRITO, A., CUZON, G., GAXIOLA, G., GARCÍA, T., TABOADA, G., SOTO, LA., BRITO, R., 2006. Energy balance of Litopenaeus vannamei, postlarvae feed on animal and vegetable protein based compounded feeds. Aquaculture, vol. 260, no. 1-4, p. 337-345.

LEMOS, D., NETTO, B. and GERMANO, A., 2006. Energy budget of juvenile fat snook Centropomus parallelus fed live food. Comparative Biochemistry and Physiology, vol. 144, no. 1, p. $33-40$.

LIMA, ER., VILELA, EF. and SANCHEZ, GR., 1998. Avaliação do Comportamento reprodutivo e do feromônio sexual sintético de Mocis latipes (GUENÉE, 1852) (Lepidoptera: Noctuidae). Anais da Sociedade Entomológica do Brasil, vol. 27, no. 1, p. 9-20.

LORENZI, H., 1982. Plantas daninhas do Brasil: terrestres, aquáticas, parasitas, tóxicas e medicinais. Nova Odessa: Editora Plantarum. LOURENÇÃO, AL., BERTI FILHO, E. and FERRAZ, MCVD., 1982. Inimigos naturais de Mocis latipes (GUENÉE, 1852). Braganthia, vol. 41, p. 238-240.

LÜBECK, GM., OLIVEIRA, JV. and ALMEIDA, RP., 1995. Análise faunística de lepidópteras coletados em duas comunidades agrícolas na zona da mata, norte de Pernambuco. Anais da Sociedade Entomológica do Brasil, vol. 24, p. 353-370.

OLIVEIRA, MC., 1997. Pragas das pastagens: uma análise crítica. Viçosa: UFV. 18 p. PANIZZI, AR. and PARRA, JRP., 1991. Ecologia nutricional de insetos e suas implicações no manejo de pragas. Brasília: CNPQ. 359 p.

PARRA, JRP., 1980. Métodos para medir consumo e utilização de alimentos por insetos. In Anais do 6 Congresso Brasileiro de Entomologia. p. 77-1026.

PETRWSEWICZ, K. and MACFADYEN, A., 1970. Productivity of terrestrial animals. principles and methods. [S.1.]: Buckwell Scientific Publications. 190 p. (IBP Handbook, 13)

RATSAK, CH., 2001. Effects of Nais elinguis on the performance of an activated sludge plant. Hydrobiologia, vol. 463, no. 1-3, p. $217-222$.

REINERT, JA., 1975. Life history of the stripped grassworm, Mocis latipes. Entomology Society of American, vol. 68, no. 2, p. 201-204.
SALLES, FM., GONÇALVES, MFB., MARTINS, OFG. and MENDES, C., 1979. Insetos e outros artrópodos de importância econômica agrícola, em perímetro irrigado e de sequeiro do Estado do Piauí. Fitossanidade, vol. 3, p. 12-19.

SANTOS, ZFDAF., FERRAZ, MCVD. and MASCARENHAS, JC., 1994. Controle de Mocis latipes no Estado da Bahia. Salvador: EBDA. 13 p.

SANTOS, LM., REDAELLI, LR., DIEFENBACH, LMG. and EFROM, CFS., 2003. Larval and pupal stage of Spodoptera frugiperda (J. E. Smith) (Lepidoptera: Noctuidae) in sweet and field corn genotypes. Brazilian Journal of Biology, vol. 63, no. 4, p. $627-633$.

SCRIBER, JM. and SLANSKY Jr., F., 1981. The nutritional ecology of immature insects. Annual Review of Entomology, vol. 26, p. 183- 211 .

SILVA, RA. and CARVALHO, CF., 1986. Aspectos Biológicos de Mocis latipes (Guinèe, 1852) (Lepidoptera-Noctuidae) em folhas de milho e arroz em condições de laboratório. Ciência e Prática, vol. 10, p. 94-101.

SILVA, RA., CARVALHO, CF. and MATIOLI, JC., 1991. Efeito de diferentes dietas na biologia da fase adulta de Mocis latipes (GUENÉE, 1852) (Lepidoptera: Noctuidae). Pesquisa Agropecuária Brasileira, vol. 26, no. 1, p. 45-50.

SILVA, AB., SOUZA, LA. and CELESTIANO FILHO, P., 1994. Resistência de gramíneas forrageiras ao ataque de Mocis latipes (GUEN, 1852). Belém: EMBRAPA 13 p. (Boletim de Pesquisa, 151)

SILVA, AG., GONÇALVES, CR., GALVÃO, DM., GONÇALVES, AJL., GOMES, J., SILVA, MN. and SIMONI, L., 1968. Quarto catálogo dos insetos que vivem nas plantasdo Brasil, seus parasitos e predadores: serviço de defesa sanitária vegetal. Brasília: Ministério da Agricultura. 622 p. (parte II, tomo 1)

STATSOFT, 2003. Statistica: data analysis software system. Version 6. Available from: <http://www.statsoft.com>.

van OIJEN, M., RUITER, FJ. and van HAREN, RJF., 1995. Analysis of the effects of potato cyst nematodes Globodera pallida on growth, physiology and yield of potato cultivars in field plots at three levels of soil compaction. Annals of Applied Biology, vol. 127, no. 3, p. 499-520.

VALÉRIO, JR., 1997. Lagarta das pastagens. [S.1.]: EMBRAPA. 3 p. (Gado de Corte Divulga, 6)

WALCZYNSKA, A., 2007. Energy budget of wood-feeding larvae of Corymbia rubra (Coleoptera: Cerambycidae). European Journal of Entomoly, vol. 104, no. 2, p. 181-185.

WUENSCHEL, MJ., JUGOVICH, AR. and HARE, JA., 2004. Effect of temperature and salinity on the energetics of juvenile gray snapper (Lutjanus griseus): implications for nursery habitat value. Journal of Experimental Marine Biology and Ecology, vol. 312, no. 2, p. 333-347.

ZANUNCIO, TV., NASCIMENTO, EC., ZANUNCIO, JC. and LOBO, PRR., 1995. Lepidópteros associados a Eucalyptus grandis HILL ex Maiden em Correntina, Bahia. Anais da Sociedade Entomológica do Brasil, vol. 24, p. 639-643. 
